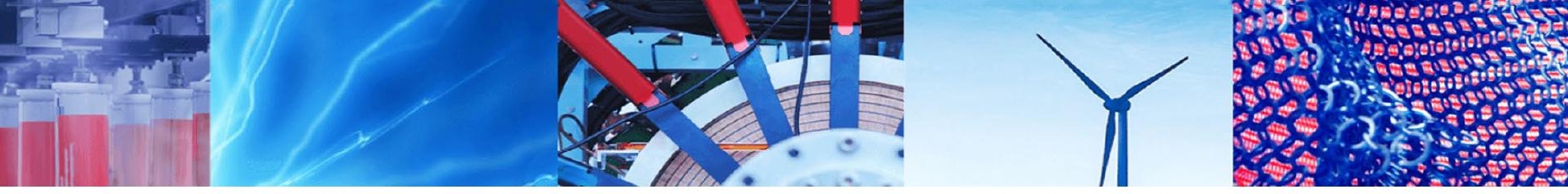

Short Communication

\title{
Modeling and experimental study of cascade solar still
}

\author{
Nidal Mouhsin ${ }^{1}\left[\right.$ D $\cdot$ Mariam Bouzaid ${ }^{1} \cdot$ Mourad Taha-Janan $^{1} \cdot$ Mohamed Oubrek $^{1}$
}

Received: 14 October 2019 / Accepted: 13 March 2020 / Published online: 19 March 2020

(c) Springer Nature Switzerland AG 2020

\begin{abstract}
In this study, a simulation was done to validate the experimental data of the new design of a cascade solar still, obtained from our existing prototype, for the climatic condition of Rabat, Morocco $\left(34^{\circ} 47^{\prime} \mathrm{N}\right)$. The new design for the cascade solar still was developed using ANSYS FLUENT and modeled using FLUENT software. It has been found that the extracted data from the simulation's results are in good agreement with the experimental data. It was also examined that the productivity of the cascade solar still was higher from 12:00 to 15:00 h. This novel design of the cascade solar still ensures higher productivity than the single basin. Based on experimental results of the new design of the cascade solar still, the results show that the absorber plate temperature and productivity can reach more than $60^{\circ} \mathrm{C}$ and $1.6 \mathrm{~kg} / \mathrm{m}^{2} \mathrm{~h}$ respectively. In comparison with the single basin, the plate temperature reaches more than $50^{\circ} \mathrm{C}$ and the productivity $0.6 \mathrm{~kg} / \mathrm{m}^{2} \mathrm{~h}$.
\end{abstract}

Keywords Component · Desalination · Brackish water C CFD · ANSYS · Stepped solar still · Cascade solar still

\section{Introduction}

Water is a basic necessity for all living species including humans, animals, and plants. The earth's surface is covered by approximately $71 \%$ water, in which $96.5 \%$ is found in the ocean, $1.4 \%$ in groundwater and $1.7 \%$ as glaciers and ice caps, while drinkable water on the earth is only $2.5 \%$.

The growth of population, water pollution, bad water management, and other big problems [1] related to water lead to an increase in consumption and prospection of drinkable water. There are different methods [2] to purifying brackish water, such as electrodialysis, multi-stage flash desalination, multi-stage heating etc. The major part of these technologies [3] are consuming high energy from a mechanical or electrical source.

Solar desalination is one of the economical applicable techniques to purify brackish water. The most popular device used is the solar still because it offers simple construction and fabrication. The main advantage of using solar stills is that it is clean and has no adverse effect on the environment. However, in comparison with other methods, the productivity is very low.

Therefore, many researchers executed different techniques to enhance the productivity of this type of desalination. They observed that the depth of saline water in the absorber plate has a big effect on the yield of the solar still. According to Kabeel et al. [4], productivity reaches almost $57.3 \%$ while using a number of trays with different widths and depths. Sammul Hansen et al. [5] used various wick materials on different absorber plates; the production rate increased from 48.9 to $72.2 \%$. Mohammed and Tabrizi [6] increased productivity by $32 \%$, by the integration of PCM in the cascade solar still. Awad and Agzouz [7] used a stepped solar still with humidification and dehumidification, increasing productivity by about $57 \%$ and the efficiency by $47 \%$. Yadav et al. [8] used a stepped and weir type solar which still increased the distillate output by around $60-80 \%$. Zoori et al. [9] used energy and exergy in a weir type cascade solar still. The efficiency of energy and exergy increased by $83.3 \%$ and $10.5 \%$ respectively.

\footnotetext{
$\triangle$ Nidal Mouhsin, mouhsin.nidal@gmail.com | 'Laboratoire de Mécanique Appliquée et Technologies, Centre de Recherche en Sciences et Technologies Industrielles et de la Santé, ENSET, Rabat-Instituts, Mohammed V University in RABAT, Avenue de I'Armée Royale, BP 6207, Rabat, Morocco.
} 
In seeking an improvement in the productivity of a solar still, our work presents a 3D CFD model of the novel cascade solar still design developed with ANSYS Workbench then simulated by FLUENT in order to validate the proposed design. A comparison was made with experimental results and simulation results of the cascade solar still.

\section{Structure of solar still}

The new device was developed by Bouzaid et al. [10] and has an inclined glass cover with an angle of $30^{\circ} \mathrm{C}$. The absorber plate is formed with a number of steps. Baffles were joined to horizontal and inclined surfaces of $35^{\circ} \mathrm{C}$ and weirs to minimize the velocity of saline water.

The details of different elements and parts of this device are explained by Bouzaid et al. [11] and presented in Figs. 1 and 2.

The solar still has a top cover made of glass. The glass cover has two functions:

- First, solar radiation passes through the glass cover, which prevents the radiation from being transmitted by the inner face of the basin with a low temperature.

- Second, the glass cover presents a condensing surface of the steam (a good wettability is necessary).

The glass was inclined over more than $25^{\circ} \mathrm{C}$ for better orientation relative to the sun and to facilitate the runoff of condensated water to the collector (Fig. 2).

The basin and the absorber plate are made of aluminum and painted black. It consists of horizontal and sloped surfaces with a black, metal baffle on the inner face. The thermal insulation is achieved by a coating

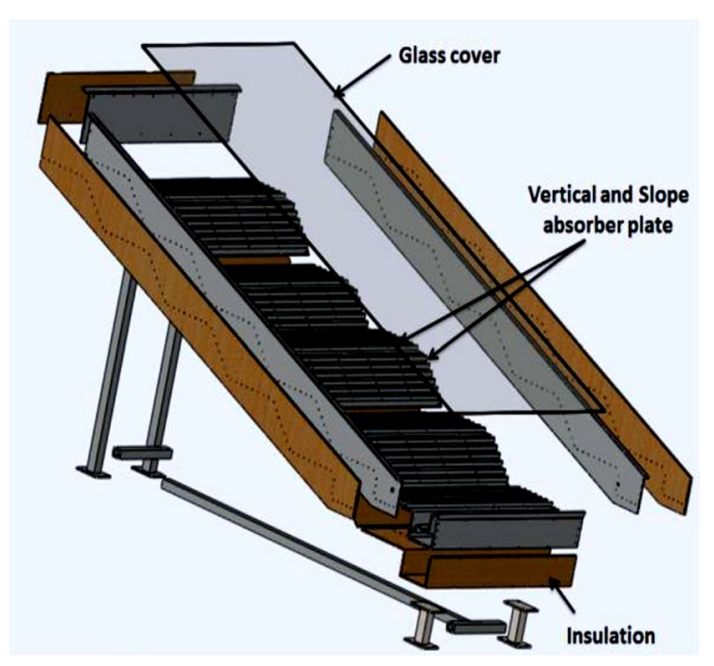

Fig. 1 Elements and parts of new design for cascade solar still [11]

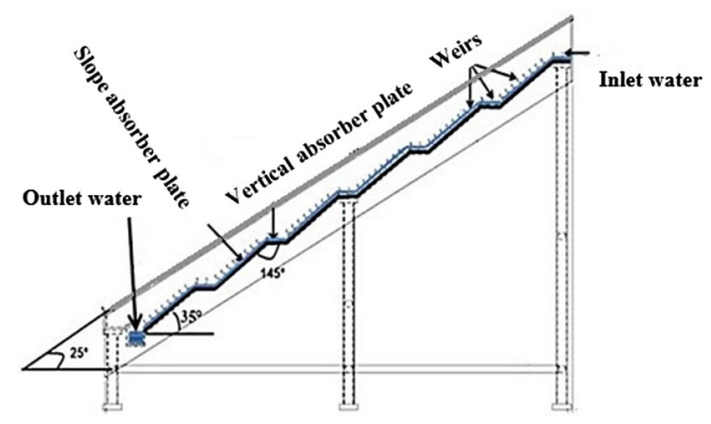

Fig. 2 The simplified design of the stepped absorber plate [11]

inside the basin. The basin bottom sealing is achieved with a synthetic rubber covering mat. Thermal insulation is achieved with a coating inside the basin.

The main advantages of the new construction of the absorber plate are:

- Better absorption of solar radiation.

- Minimum depth of water.

- Quick water heating.

\section{Design modeling with ANSYS}

The 3D geometry of the solar still was modeled using ANSYS Design Modeler with all the same geometrical constraints as in the experimental set-up.

It is the gate to the geometry manipulation for analysis with software from ANSYS, and it necessitates special care for defining surfaces and boundaries.

\subsection{ANSYS meshing}

The most critical part of the simulation is mesh generation. Too many cells may result in long solver runs, and too few may lead to inaccurate results. Meshing technology of ANSYS provides balancing requirements and gets the correct mesh for every simulation in the most automatic way possible. The most powerful parts of these tools are transported in a single environment to obtain a powerful meshing.

The grid independence test has been effectuated to verify the mesh size for the model. The convergence criteria were achieved for continuity, velocity, $k-\varepsilon\left(1 \mathrm{e}^{-3}\right)$ and the energy Eq. $\left(1 \mathrm{e}^{-6}\right)$ at each time step. The grid size was specified by increasing the number of meshes until the criterion $[p-(p+1)] / p<10^{-3}$ was satisfied.

With: $p$ : The calculated temperature using current mesh size. 
$p+1$ : The temperature using the next mesh size.

The air temperature inside the cascade solar still was evaluated for the grid independence study.

Figure 3a shows the geometry meshed using 3D hexahedral meshing consisting of a total of 2.8 million cells.

Figure $3 \mathrm{~b}$ shows the computational domain that was used for this study.

\subsection{ANSYS solution processor}

The solution obtained by using this process for the finite element model generated in the preprocessor.

The important tasks in this processor are:

- Defining analysis types and options.

- Specifying boundary conditions.

- Obtaining a solution.

The numerical studies were based on the following assumptions:

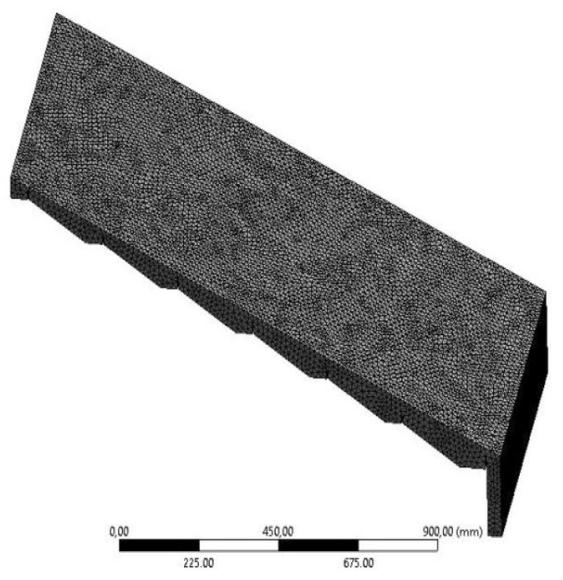

a

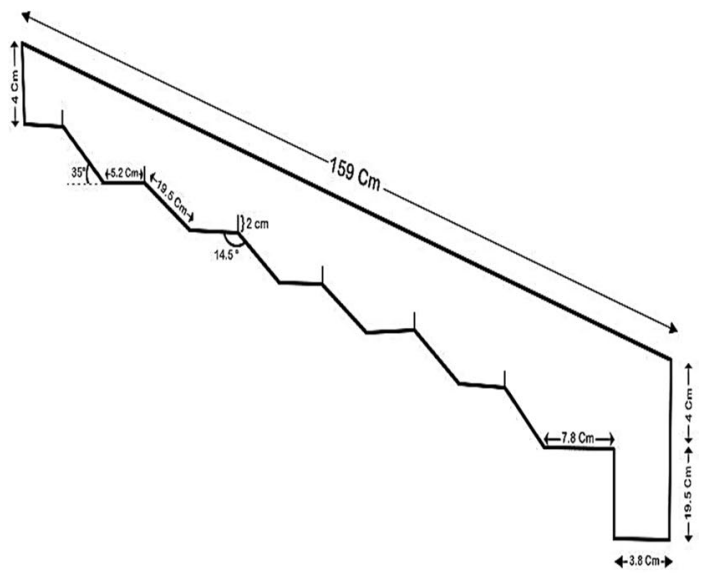

b

Fig. 3 a Mesh Geometry of Model b The computational domain of cascade solar still
- Thermo-physical properties of aluminum, glass, and air remain constant during the process.

- Thermal contact between the glass and the walls of the cascade solar still and their environment is perfect.

- The cascade solar still wall temperature is considered equal and undisturbed.

\subsection{Boundary conditions}

The boundary conditions are specified to solve the continuity and momentum equations. The running simulation was about $10 \mathrm{~h}$ due to a high number of time steps and computer time constraints. The received solar radiation by the basin, the ambient temperature, and the water and glass temperatures were based on the solar calculator in fair weather conditions. The solar intensity was based on the absorption factor and the emissivity of the glass, the bottom of the basin, and the water. The heat transfer coefficient of the side walls was calculated and maintained at a constant for the overall process.

\section{Experimental procedure}

The experiment was realized from 8 am to $6 \mathrm{pm}$. For each 1-h time interval, an average temperature was set as the boundary condition.

The cascade solar still is fed with $25 \mathrm{~L}$ of saltwater linked to a saline storage tank. Six thermocouples are installed at the inner face of the absorber plate and three on the external face of the glass cover. Three measurements were carried on the absorber: the top, middle, and bottom. The solar intensity and the ambient temperature are collected during the experimental process, which is realized at the Higher Normal School of Technical Education in Rabat, Morocco $\left(34^{\circ} 47^{\prime} \mathrm{N}\right)$.

One of the important input parameters for modeling is the solar intensity. In this study, the solar intensity data used is obtained from the energy laboratory of ENSET -Rabat Other sets of model parameters and their corresponding values are listed in Table 1. 
Table 1 Model parameters and still specifications

\begin{tabular}{lll}
\hline Parameter & Symbol & Value \\
\hline Specific heat of glass cover & $\mathrm{C}_{\mathrm{g}}(\mathrm{j} / \mathrm{kg} \cdot \mathrm{K})$ & 800 \\
Specific heat of brackish water & $\mathrm{C}_{\mathrm{w}}(\mathrm{j} / \mathrm{kg} \cdot \mathrm{K})$ & 4190 \\
Specific heat of absorber plate & $\mathrm{C}_{\mathrm{b}}(\mathrm{j} / \mathrm{kg} \cdot \mathrm{K})$ & 896 \\
Specific heat of insulation material & $\mathrm{C}_{\mathrm{ins}}(\mathrm{j} / \mathrm{kg} \cdot \mathrm{K})$ & 670 \\
Thermal conductivity of glass cover & $\lambda_{\mathrm{g}}(\mathrm{W} / \mathrm{m} \mathrm{K})$ & 1.02 \\
Thermal conductivity of brackish water & $\lambda_{\mathrm{w}}(\mathrm{W} / \mathrm{m} \mathrm{K})$ & 0.67 \\
Thermal conductivity of absorber plate & $\lambda_{\mathrm{b}}(\mathrm{W} / \mathrm{m} \mathrm{K})$ & 73 \\
Thermal conductivity of insulation material & $\lambda_{\text {ins }}(\mathrm{W} / \mathrm{m} \mathrm{K})$ & 0.059 \\
Density of glass cover & $\rho_{\mathrm{g}}\left(\mathrm{kg} / \mathrm{m}^{3}\right)$ & 2530 \\
Density of brackish water & $\rho_{\mathrm{w}}\left(\mathrm{kg} / \mathrm{m}^{3}\right)$ & 1022 \\
Density of absorber plate & $\rho_{\mathrm{b}}\left(\mathrm{kg} / \mathrm{m}^{3}\right)$ & 2700 \\
Density of insulation material & $\rho_{\text {ins }}\left(\mathrm{kg} / \mathrm{m}^{3}\right)$ & 200 \\
Absorber plate area & $\mathrm{A}_{\mathrm{b}}\left(\mathrm{m}^{2}\right)$ & 1.53 \\
Glass cover area & $\mathrm{A}_{\mathrm{g}}\left(\mathrm{m}^{2}\right)$ & 1.56 \\
Air molecular weight & $\mathrm{Ma}(\mathrm{kg} / \mathrm{kmol})$ & 29 \\
Water molecular weight & $\mathrm{Mw}(\mathrm{kg} / \mathrm{kmol})$ & 18 \\
Water surface absorptivity & $\mathrm{a}_{\mathrm{w}}$ & 0.9 \\
Glass cover absorptivity & $\mathrm{a}_{\mathrm{g}}$ & 0.052 \\
\hline
\end{tabular}

\section{Mathematical modeling}

\subsection{Governing equations}

The governing equations of this problem are presented as follows:

- Continuity equation:

$\frac{\partial \rho}{\partial t}+\nabla \cdot(\rho V)=0 \quad \nabla \cdot(\rho V)=0$

- Momentum equations:

X-component: $\frac{\partial(\rho u)}{\partial t}+\nabla \cdot(\rho u V)=-\frac{\partial p}{\partial x}+\frac{\partial \tau x x}{\partial x}+\frac{\partial \tau y x}{\partial y}$ $+\frac{\partial \tau z x}{\partial z}+\rho f_{x}$

$y$-component: $\frac{\partial(\rho v)}{\partial t}+\nabla \cdot(\rho u V)=-\frac{\partial p}{\partial y}+\frac{\partial \tau x x}{\partial x}+\frac{\partial \tau y x}{\partial y}$ $+\frac{\partial \tau z x}{\partial z}+\rho f_{y}$

z-component: $\frac{\partial(\rho w)}{\partial t}+\nabla \cdot(\rho w V)=-\frac{\partial p}{\partial z}+\frac{\partial \tau x x}{\partial x}+\frac{\partial \tau y x}{\partial y}$ $+\frac{\partial \tau z x}{\partial z}+\rho f_{z}$

- Energy equation:

$$
\begin{aligned}
\frac{\partial}{\partial t}\left[\rho\left(e+\frac{\mathrm{V} 2}{2}\right)\right]+\nabla \cdot\left[\rho\left(e+\frac{\mathrm{v}^{2}}{2} \vec{V}\right)\right] \\
=\rho \dot{q}+\frac{\partial}{\partial x}\left(k \frac{\partial T}{\partial x}\right)+\frac{\partial}{\partial y}\left(k \frac{\partial T}{\partial y}\right)+\frac{\partial}{\partial z}\left(k \frac{\partial T}{\partial z}\right) \\
\quad-\frac{\partial(u p)}{\partial x}-\frac{\partial(v p)}{\partial y}-\frac{\partial(w p)}{\partial z}+\frac{\partial(u \tau x x)}{\partial x}+\frac{\partial(u \tau y x)}{\partial y} \\
\quad+\frac{\partial(u \tau z x)}{\partial z}+\frac{\partial(v \tau x y)}{\partial x}+\frac{\partial(v \tau y y)}{\partial y}+\frac{\partial(v \tau z y)}{\partial z} \\
\quad+\frac{\partial(w \tau x z)}{\partial x}+\frac{\partial(w \tau y z)}{\partial y}+\frac{\partial(w \tau z z)}{\partial z}+\rho \vec{f} \cdot \vec{V}
\end{aligned}
$$

\subsection{Energy balance}

The all various thermal energy balance of cascade solar still are explained by Bouzaid [12]

- Thermal energy balance of the condensing glass cover

The thermal energy balance for the glass cover is expressed by:

$C_{p g m g} \frac{d T g}{d t}=Q_{r w g}+Q_{c w g}+Q_{e w g}-Q_{r g s k y}-Q_{c g a}+P_{g}$

The radiative heat flux density between the glass cover and the sky:

$\mathrm{Q}_{\text {rgsky }}=\mathrm{h}_{\text {rgsky }} \mathrm{A}_{\mathrm{g}}\left(\mathrm{T}_{\mathrm{g}}-\mathrm{T}_{\text {sky }}\right)$

$\mathrm{h}_{\text {rgsky }}$ : the radiative heat exchange coefficient between the glass cover and the sky:

$\mathrm{h}_{\text {rgsky }}=\sigma \varepsilon_{\mathrm{w}}\left(\mathrm{T}_{\mathrm{g}}^{2}+\mathrm{T}_{\text {sky }}^{2}\right)\left(\mathrm{T}_{\mathrm{g}}+\mathrm{T}_{\text {sky }}\right)$, where $\mathrm{T}_{\text {sky }}=0.0552\left(\mathrm{~T}_{a}^{1.5}\right)$.

The convective heat flux density between the glass cover and the ambient air:

$\mathrm{Q}_{\text {cga }}=\mathrm{h}_{\mathrm{cga}} \mathrm{A}_{\mathrm{g}}\left(\mathrm{T}_{\mathrm{g}}-\mathrm{T}_{\mathrm{a}}\right)$

Where $h_{\text {cga }}$ the convective heat exchange coefficient between the glass cover and the ambient air:

$\mathrm{h}_{\text {cga }}=5.8+3.8 \mathrm{~V}$

$V$ is the wind velocity average.

The radiative heat flux density between the brackish water and the glass cover:

$\mathrm{Q}_{\mathrm{rwg}}=\mathrm{h}_{\mathrm{rwg}} \mathrm{A}_{\mathrm{w}}\left(\mathrm{T}_{\mathrm{g}}-\mathrm{T}_{\mathrm{w}}\right)$

Where hrwg the radiative heat exchange coefficient between the brackish water and the glass cover: 
$h_{r w g}=\frac{\sigma(\operatorname{Tw} 2+\operatorname{Tg} 2)(\operatorname{Tw}+\operatorname{Tg})}{\frac{1}{\varepsilon w}+\frac{1}{\varepsilon g}-1}$

$\varepsilon_{\mathrm{w}}$ the brackish water emissivity; $\varepsilon_{\mathrm{g}}$, the glass cover emissivity; $\sigma$, the Stefan-Boltzman constant.

The convective heat flux density between the brackish water and the glass cover:

$\mathrm{Q}_{c w g}=\mathrm{h}_{c w g} \mathrm{~A}_{\mathrm{w}}\left(\mathrm{T}_{\mathrm{g}}-\mathrm{T}_{\mathrm{w}}\right)$

$\mathrm{h}_{\mathrm{cwg}}$, the convective heat exchange coefficient between the brackish water and the glass cover.

The evaporative heat flux density between the brackish water and the glass cover:

$\mathrm{Q}_{\mathrm{ewg}}=\mathrm{h}_{\mathrm{ewg}} \mathrm{A}_{\mathrm{w}}\left(\mathrm{T}_{\mathrm{g}}-\mathrm{T}_{\mathrm{w}}\right)$

$\mathrm{h}_{\text {ewg }}$, the evaporative heat exchange coefficient between the brackish water and the glass cover.

$h_{\text {ewg }}=16.273 \times 10^{-3} h_{c w g} \frac{(P w-P g)}{(T w-T g)}$

$\mathrm{P}_{\mathrm{w}}$, the water vapor pressures at the brackish water; $\mathrm{P}_{\mathrm{g}}$, the water vapor pressures at the glass cover.

$P_{w}=\exp \left(25.317-\frac{5144}{T w+273.15}\right)$

$P_{g}=\exp \left(25.317-\frac{5144}{\operatorname{Tg}+273.15}\right)$

$\mathrm{P}_{\mathrm{g}}$ : The absorbed fraction of the incident heat flux density on the glass cover of the solar still.

$P_{g}=I_{G} A_{g} \alpha_{g}$

- Thermal energy balance of the brackish water:

The thermal energy balance for the brackish water is expressed by:

$C_{p w} m_{w} \frac{d T w}{d t}=Q_{c b w}-Q_{r w g}-Q_{c w g}-Q_{e w g}+P_{w}$

The convective heat flux density between the basin liner and the brackish water:

$\mathrm{Q}_{\mathrm{cbw}}=\mathrm{h}_{\mathrm{cbw}} \mathrm{A}_{\mathrm{b}}\left(\mathrm{T}_{\mathrm{b}}-\mathrm{T}_{\mathrm{w}}\right)$

$\mathrm{h}_{\mathrm{cbw}}$ : the convective heat exchange coefficient between the basin liner and the brackish water, it is obtained from the correlation of Nusselt number, following Kreith [13]:
- If $\mathrm{Gr}<10^{5 ;} \mathrm{Nu}=1$

$\mathrm{h}_{\mathrm{cbw}}=\frac{\lambda \mathrm{w}}{\mathrm{Lb}}$

- If $10^{5}<\mathrm{Gr}<2 \times 10^{7} ; \mathrm{Nu}=0.54(\mathrm{Gr} \mathrm{Pr})^{0.25}$

$\mathrm{h}_{\mathrm{cbw}}=\frac{\mathrm{Nu} \lambda \mathrm{w}}{\mathrm{Lb}}$

- If $\mathrm{Gr}>2 \times 10^{7 ;} \mathrm{Nu}=0.14(\mathrm{Gr} P r)^{0.25}$

$\mathrm{h}_{\mathrm{cbw}}=\frac{\mathrm{Nu} \lambda \mathrm{w}}{\mathrm{Lb}}$

Where Gr, Nu, and Pr are respectively the non-dimensional Grashof, Nusselt and Prandlt numbers.

$\mathrm{P}_{\mathrm{w}}$, The solar power absorbed by the brackish water.

$\mathrm{P}_{\mathrm{w}}=\mathrm{I}_{\mathrm{G}} \mathrm{A}_{\mathrm{w}} \alpha_{\mathrm{w}} \tau_{\mathrm{g}}$

- Thermal energy balance of the absorber plate:

The thermal energy balance for the absorber plate is expressed by:

$C_{p b} m_{b} \frac{d T b}{d t}=-Q_{c b w}-Q_{c d}+P_{b}$

$\mathrm{Q}_{c d}$ : The conductive heat flux density of the basin

$\mathrm{Q}_{c d}=\frac{\lambda \mathrm{b}}{\mathrm{eb}} \mathrm{A}_{\mathrm{b}}\left(\mathrm{T}_{\mathrm{b}}-\mathrm{T}_{\mathrm{a}}\right)$

$\lambda_{b}$, the thermal conductivity; $e_{b}$, the thickness of the absorber plate; $\mathrm{P}_{\mathrm{b}}$, The solar power absorbed by the basin liner.

$\mathrm{P}_{\mathrm{b}}=\mathrm{I}_{\mathrm{G}} \mathrm{Ab} \alpha_{\mathrm{b}} \tau_{\mathrm{g}} \tau_{\mathrm{w}}$

For the novel absorber plate the solar power absorbed by the basin is expressed by:

$P_{b}=P_{H b}+P_{l b}$

$\mathrm{P}_{\mathrm{Hb}}$, the solar power absorbed by the horizontal surface of the absorber plate.

$\mathrm{P}_{\mathrm{Hb}}=\mathrm{I}_{\mathrm{G}} \mathrm{A}_{\mathrm{Hb}} \alpha_{\mathrm{b}} \tau_{\mathrm{g}} \tau_{\mathrm{w}}$

$\mathrm{P}_{\mathrm{Ib}}$, the solar power absorbed by the inclined surface of the absorber plate.

$P_{\mathrm{lb}}=\mathrm{I}_{\mathrm{G}} \mathrm{A}_{\mathrm{lb}} \alpha_{\mathrm{b}} \tau_{\mathrm{g}} \tau_{\mathrm{w}}$ 
- Thermal energy balance equation for the inner face of insulation material:

The thermal energy balance for the inner face of insulation is expressed by:

$\mathrm{C}_{\mathrm{p}, \mathrm{ins}} \mathrm{M}_{\mathrm{ins}} \frac{d T i, \text { ins }}{d t}=-\mathrm{Q}_{\mathrm{cd}, \mathrm{ins}}+\mathrm{Q}_{\mathrm{cd}}$

$\mathrm{Q}_{\mathrm{cd}, \text { ins }}$, the conductive heat flux density of the insulation material.

$\mathrm{Q}_{\text {cd,ins }}=\frac{\lambda \text { ins }}{\text { eins }}-\mathrm{A}_{\text {ins }}\left(\mathrm{T}_{\mathrm{i}, \mathrm{ins}}-\mathrm{T}_{\mathrm{e}, \mathrm{ins}}\right)$

$e_{\text {ins }}$ the thickness of the insulation material; $\lambda_{\text {ins, }}$ the thermal conductivity of the insulation material.

- Thermal energy balance equation for the external face of insulation material:

The thermal energy balance for the external face of insulation is expressed by:

$C_{p, \text { ins }} M_{\text {ins }} \frac{d T i, \text { ins }}{d t}=-\left(Q_{r, i a}+Q_{c, i a)}+Q_{c d, i n s}\right.$

$\mathrm{Q}_{\mathrm{r}, \mathrm{i} a}$ the radiative heat flux density between the insulation material and the ambient air.

$\mathrm{Q}_{\mathrm{r}, \text { ins }}=\mathrm{h}_{\mathrm{r}, \text { ins }} \mathrm{A}_{\mathrm{b}}\left(\mathrm{T}_{\mathrm{e} \text {,ins }}-\mathrm{T}_{\mathrm{a}}\right)$

$\mathrm{h}_{\mathrm{r}, \mathrm{ins}}$, the radiative heat exchange coefficient between the external face of insulation and ambient air is given by Stefan Boltzmann law.

$h_{r, \text { ins }}=\sigma \varepsilon\left(T_{e, i n s}^{2}+T_{a}^{2}\right)\left(T_{e, i n s}+T_{a}\right)$

$\mathrm{Q}_{\mathrm{c}, \mathrm{i} a}$, the convective heat flux density existed between the external face of insulation and the ambient air.

$\mathrm{Q}_{\mathrm{c}, \mathrm{ia}}=\mathrm{h}_{\mathrm{c}, \mathrm{ia}}\left(\mathrm{T}_{\mathrm{e}, \mathrm{ins}}-\mathrm{T}_{\mathrm{a}}\right)$

where $h_{c, i a}$ the convective heat exchange coefficient exchanged between the insulation and the ambient air.

$h_{c, i a}=1.78 \times \mid$ Te,ins - Tsky $\left.\right|^{0.25}$

\section{Simulation results and discussion}

The results obtained from the simulation analysis and experimental study of a cascade solar still presented in this section.

The main objective of this study was to develop a CFD model of a cascade solar still to validate the results with experimental data. A multi-phase model has been developed in ANSYS which accounts for all three phases that are present in the cascade solar still (air, liquid water, vapor). The simulation results have been linked with the experimental data, and it is observed that experimental and simulated data follow the same pattern.

Figure 4 shows the temperature experiment and simulation of the basin. As can be seen, the simulation outcomes have been compared with the experimental data. The readings don't exactly match, but they follow similar patterns. The likely reason for this variation is that the intensity of solar radiation in the simulation doesn't account for natural attenuation.

In Fig. 5, the simulation results of solar intensity have been compared with the experimental data. The compared results are perfectly matched, and it follows a similar pattern.

Figure 6 shows the variation of the absorber temperature has a similar variation to the solar intensity. The absorber plate temperature and the solar intensity have achieved the maximum at mid-noon. The solar radiation increases, and it increases the absorber temperature to a maximum of more than $61{ }^{\circ} \mathrm{C}$ and 900 w.m2 of solar intensity.

The water productivity, as shown in Fig. 7, has achieved a maximum of $1.66 \mathrm{~kg} / \mathrm{m} 2 \mathrm{~h}$ after mid-noon. When the intensity of solar radiation increases, more distilled water is produced due to a higher temperature. After reaching its maximum, the productivity decreases as the intensity of solar radiation drops.

Figure 8 shows that the process of evaporation and condensation begins at 10:00 am. The absorber plate warms up and then warming starts increasing until 15:00 pm. Then, due to a decrease in intensity of the solar radiation, there is a loss of thermal energy. Thus, the absorber

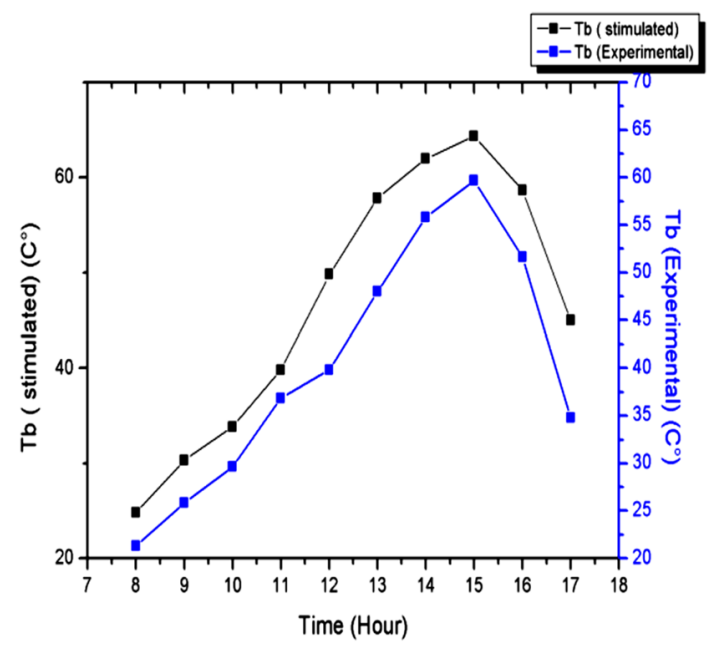

Fig. 4 The absorber plate temperature Simulated and Experimental Results 


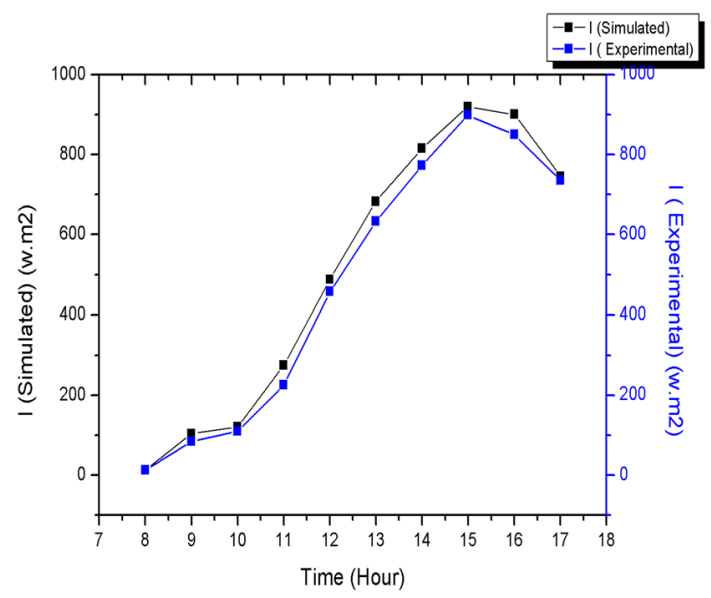

Fig. 5 Solar intensity variation of simulated and experimental data

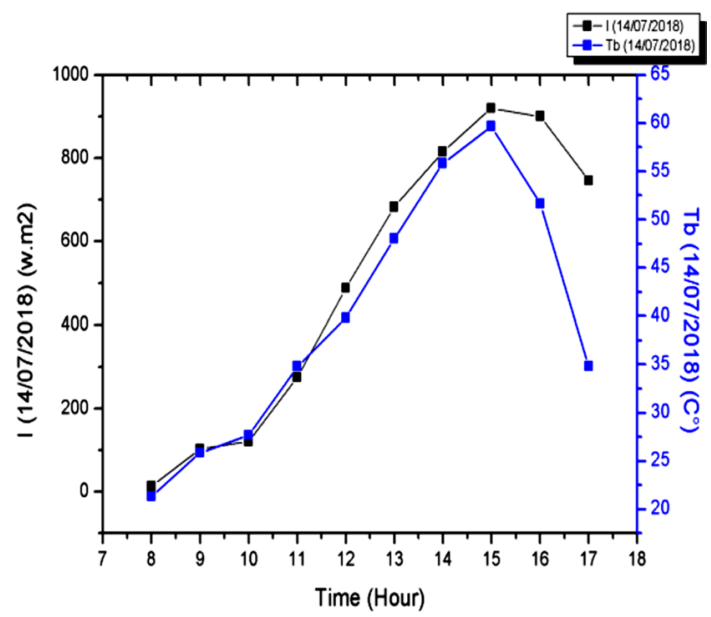

Fig. 6 Hourly variations of the absorber plate temperature measured on the 14th of July 2018

temperature declined from 15:00 to $17: 00 \mathrm{pm}$. Figures $8,9,10$ and 11 show different temperature contours obtained by ANSYS CFD simulation results from 8:00 am to $18: 00 \mathrm{pm}$.

An experimental analysis was done, the results showing that the absorber plate temperature and productivity can reach more than $60^{\circ} \mathrm{C}$ and $1.66 \mathrm{~kg} / \mathrm{m}^{2} \mathrm{~h}$ respectively. Important values proved the productivity of the new design. Compared to the experimental results of the single basin presented by Badran [14], the absorber plate

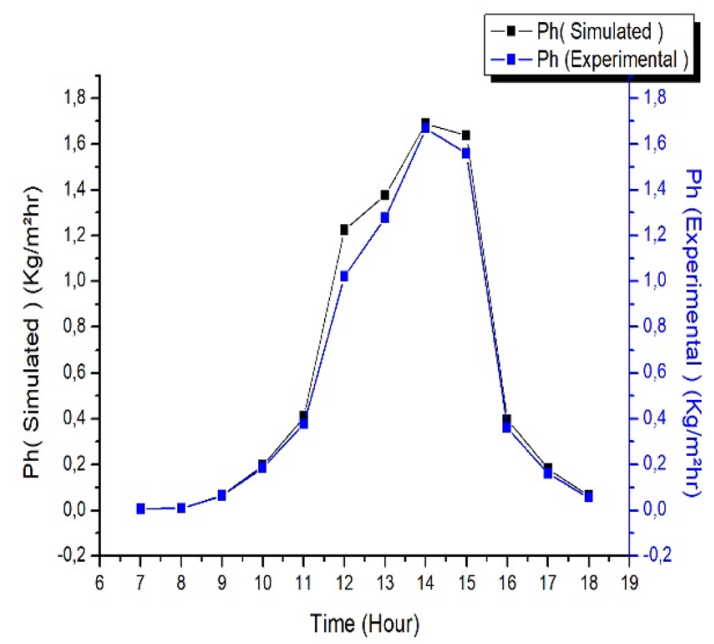

Fig. 7 Hourly productivity of the solar still (simulated/experimental)

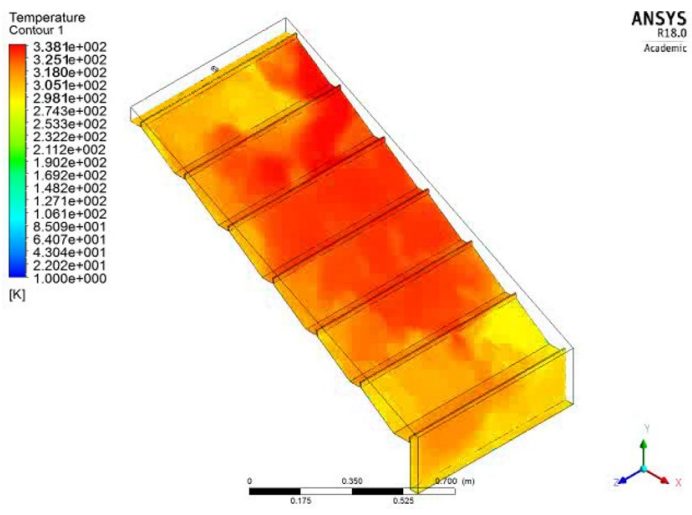

Fig. 8 Temperature contour at 10:00 am

temperature and productivity reached more than $50{ }^{\circ} \mathrm{C}$ and $0.6 \mathrm{~kg} / \mathrm{m}^{2} \mathrm{~h}$ respectively. That proves the effect of water depth on the productivity of the still basin.

Figures 12, 13 and 14 show different values of the absorber temperature and the productivity in two different seasons (autumn and summer); where important values were $49{ }^{\circ} \mathrm{C}, 0.64$ for November, $61{ }^{\circ} \mathrm{C}$ and 1.66 respectively for July as shown in Fig. 6 . Figure 14, therefore, observed that the productivity in summer was higher than in autumn because of the solar intensity effect. 

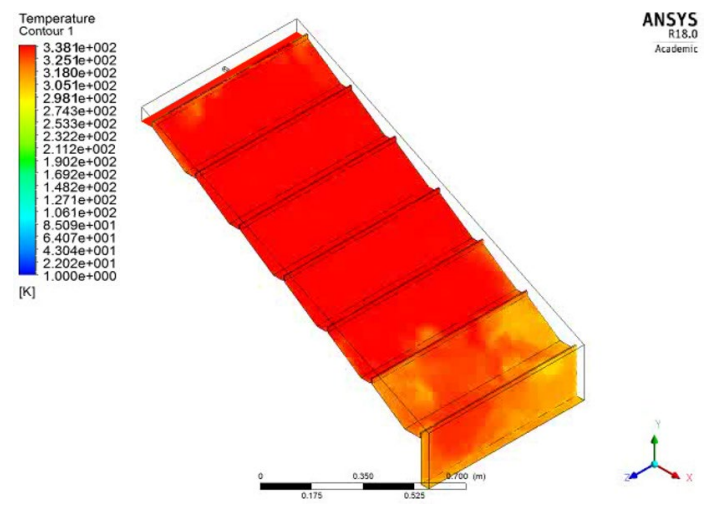

Fig. 9 Temperature contour at 15:00 pm
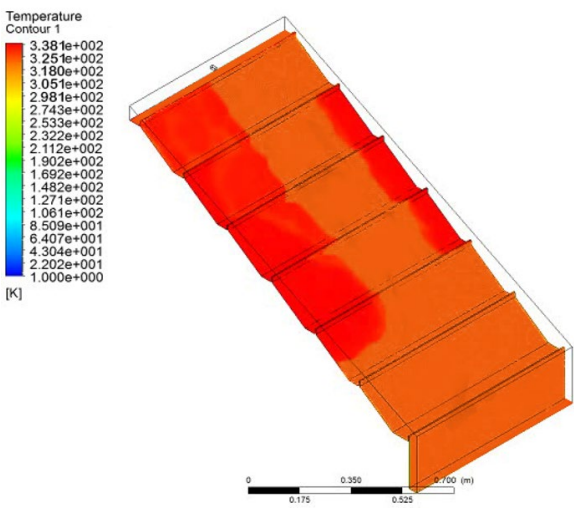

ANSYS

Fig. 10 Temperature contour at 16:00 pm
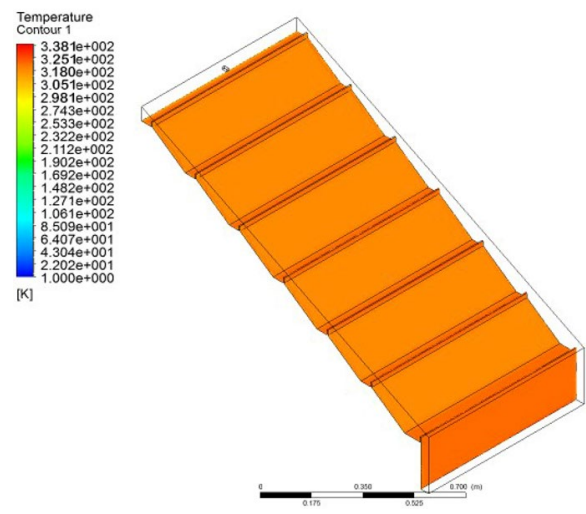

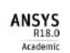<smiles>CC(C)C</smiles>

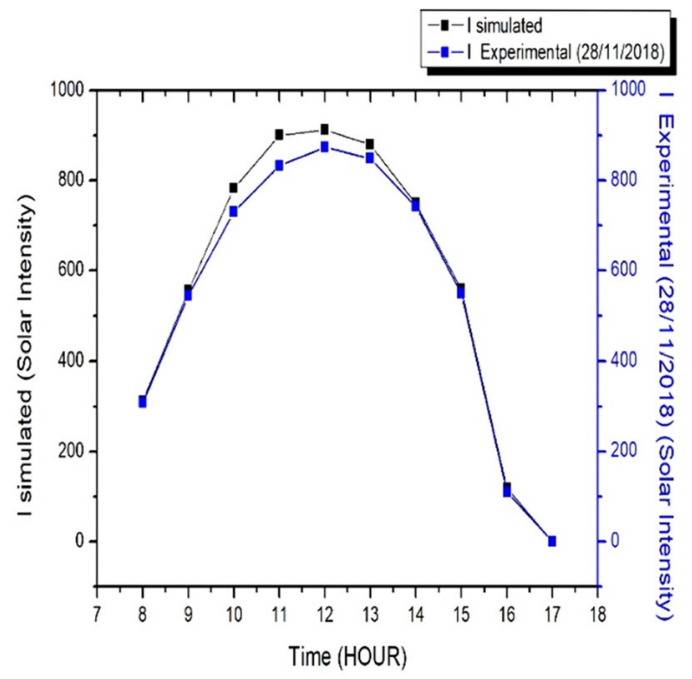

Fig. 12 Solar intensity predicted by the CFD simulation and experimental data $(28 / 11 / 2018)$

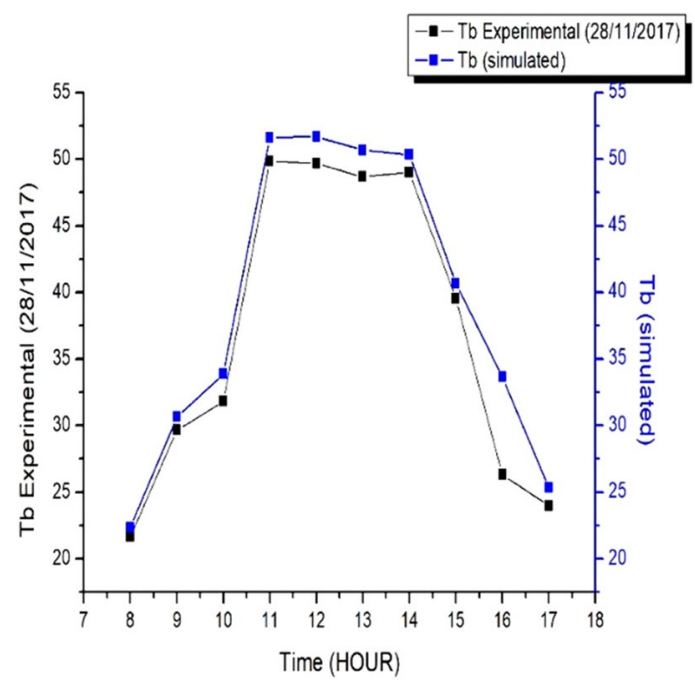

Fig. 13 Absorber temperature predicted by the CFD simulationand experimental data $(28 / 11 / 2018)$

Fig. 11 Temperature contour at 17:00 pm 


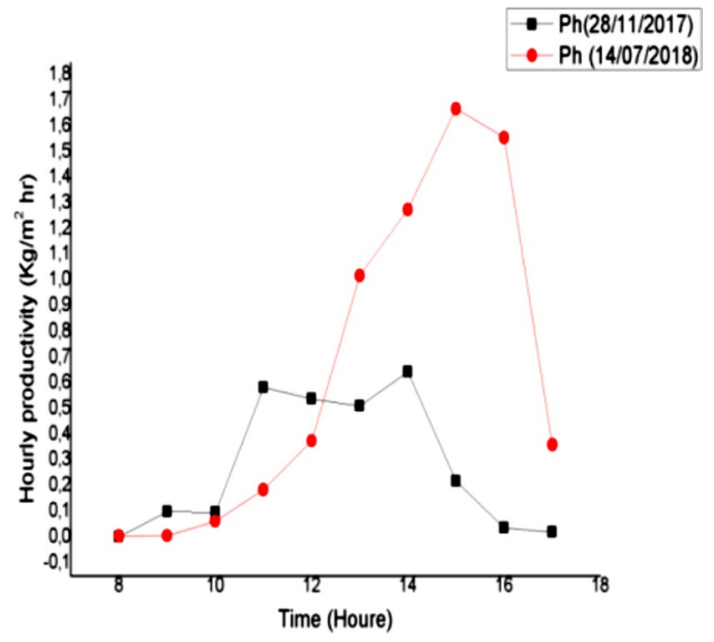

Fig. 14 Hourly productivity of the still measured on the $28 / 11 / 2017$ and $14 / 07 / 2018$

\section{Conclusion}

This paper presents a new design of the solar still with a stepped absorber plate, and sloped surfaces for minimizing the depth of saline water, which will enhance the productivity of this cheapest type of desalination. The multi-phase model was developed in ANSYS, which takes into consideration all three phases present in our prototype, (air, liquid water, water vapor). The CFD simulation was realized for the unsteady system, and the simulation results have been linked with the experimental data.

The results show the following points:

- A good agreement of absorber temperature in experimental work as well as ANSYS CFD simulation.

- A good agreement of distillate output in experimental work as well as ANSYS CFD simulation.

- The computational fluid dynamics is a very powerful tool for design parameters, diagnostics, as well as simulation of various solar stills.

- The Experimental results proved the efficiency of the new design, compared to the single basin design.

- The absorber plate temperature and productivity can reach more than $60^{\circ} \mathrm{C}$ and $1.66 \mathrm{~kg} / \mathrm{m}^{2} \mathrm{~h}$ respectively. The results of the single basin with absorber plate temperature measure more than $50{ }^{\circ} \mathrm{C}$ and productivity reach $0.6 \mathrm{~kg} / \mathrm{m}^{2} \mathrm{~h}$.

The simulation model has been tested to validate the quality and capability of the experimental model. Future work can be done by integrating more baffles to the absorber plate and considering other different design parameters.

\section{Compliance with ethical standards}

Conflict of interest The authors declare that they have no conflict of interest.

\section{References}

1. Liu C, Wang $\mathrm{H}$ (2003) An analysis of the relationship between water resources and population-economy society-environment. J Nat Resour 18(5):635-644

2. Bharadwaj R, Singh D, Mahapatra A (2008) Seawater desalination technologies. Int J Nucl Desalin 3(2):151-159

3. Reddy KV, Ghaffour N (2007) Overview of the cost of desalinated water and costing methodologies. Desalination 205:340-353

4. Kabeel AE, Khalil A, Omara ZM, Younes MM (2012) Theoretical and experimental parametric study of modified stepped solar still. Desalination 289:12-20

5. Sammul Hansen R, Surya Narayanan C, Kalidasa Murgavel K (2015) Performance analysis on inclined solar still with different new wick materials and wire mesh. Desalination 358:1-8

6. Dashtban M, Tabrizi FF (2011) Thermal analysis of a weir-type cascade solar still integrated with PCM storage. Desalination 279(1):415-422

7. Awad MM, El-Agouz SA (2013) Enhancement of the performance of stepped solar still using humidification-dehumidification processes. Nat Sci 11(2):88-98

8. Kumar M, Yadav C, Manchanda H (2016) Thermal performance of a weir-type cascade solar still: an experimental study. Int J Adv Res Innov 4(1):339-344

9. Zoori HA, Tabrizi FF, Sarhaddi F, Heshmatnezhad F (2013) Comparison between energy and exergy efficiencies in a weir type cascade solar still. Desalination 325:113-121

10. Bouzaid M, Ansari1 O, Taha-Janan M, Oubrek M (2018) Experimental and theoretical analysis of a novel cascade solar desalination still. Tech Science Press FDMP 14(3): 177-200

11. Bouzaid M, Oubrek M, Ansari O, Sabri A, Taha Janan M (2016) Mathematical analysis of a new design for cascade solar still. FDMP 12(1):15-32

12. Bouzaid M, Ansari O, Taha-Janan M, Mouhsin N, Oubrek $M$ (2019) A numerical analysis of thermal performances for a novel solar desalination still design energy procedia 157:1071-1082

13. Kreith F (1967) Transmission de la chaleur et thermodynamique. $p$ 484-488

14. Badran $\mathrm{OO}$ (2007) Experimental study of the enhancement parameters on a single slope solar still productivity. Desalination 209(1-3):136-143

Publisher's Note Springer Nature remains neutral with regard to jurisdictional claims in published maps and institutional affiliations. 